\title{
Akibat Hukum Perkawinan Yang Tidak Dicatatkan Secara Administratif Pada Masyarakat Adat
}

\author{
Agung Basuki Prasetyo \\ Fakultas Hukum Universitas Diponegoro \\ Jl. Prof. Soedarto, SH Tembalang Semarang \\ Email: agungbasukiprasetyo@gmail.com
}

\begin{abstract}
Abstrak
Pelaksanaan perkawinan di kalangan Masyarakat Hukum Adat melalui proses yang panjang atau rites de passage, karena menyatukan dua keluarga besar. Perkawinan sebagaimana yang terjadi seperti di lingkungan Masyarakat Hukum Adat Suku Samin atau Sedulur Sikep di Pati Jawa Tengan, dan Masyarakat Adat Karuhun Urang (AKUR) Kuningan Jawa Barat, tidak dicatatkan di KUA atau Kantor Catatan Sipil, namun memiliki pencatatan secara administratif tersendiri di lembaga adatnya, yakni Pranata Adanya. Akibat hukum perkawinan masyarakat Hukum Adat yang tidak mencatatkan perkawinannya secara hukum negara berdampak pada beberapa hal, seperti halnya kedudukan dan status anak yang dilahirkan, pewarisan, dampak pendidikan, dan lain sebagainya. Sedangkan akibat hukum menurut hukum adatnya tidak menjadi masalah karena perkawinan sudah memiliki pengakuan dalam tatanan kehidupan Masyarakat Hukum Adatnya. Perkawinan tersebut menimbulkan hubungan dua keluarga besar menjadi satu, serta tidak dipermasalahkan yang terkait dengan hak kedudukan anak, seperti dibidak pendidikan informal, warisan, perkawinan, dan bidang hukum adat lainnya, karena semuanya dikembalikan pada hukum adat yang berlaku dalam masyarakat Hukum Adat setempat.
\end{abstract}

Kata Kunci: Perkawinan Tidak dicatatkan, Masyarakat Hukum Adat

\begin{abstract}
The implementation of marriage among the indigenous peoples of the law through a lengthy process or rites de passage, because it brings together two large families. Marriage as is the case in the environment of indigenous people of Samin or Sedulur Sikep in Pati Jawa Tengan, and indigenous Karuhun Urang (AKUR) Kuningan West Java, not recorded in the KUA or the Civil registry office, but has Its own administrative record of the institution, the Pranata. The result of the marriage Law of Adat Law Society that does not record the legal his marriage of the country affects several things, such as the position and status of the Born child, inheritance,
\end{abstract}


impact of education, and so forth. While the legal consequences according to the law of law is not a problem because the marriage already has recognition in the life order of the law community. The marriage led to the relationship of two large families in one, and not in question related to the right of the child's position, such as the informal education, inheritance, marriage, and other customary areas of law, as it was all is returned to customary laws applicable to the local customary law community.

Keywords: Marriage not listed, indigenous peoples

\section{A. Pendahuluan}

Secara kodrat manusia, sebagai mahluk ciptaan Tuhan Yang Maha Esa yang berjenis kelamin laki-laki dan perempuan, sangat wajar jika saling mengikatkan diri untuk membentuk sebuah keluarga, yang lazim dapat disebut suami isteri. Ikatan tersebut tentunya didasarkan pada kaidah-kaidah hukum yang berlaku.

Ikatan antara seorang pria dengan seorang wanita untuk membentuk sebuah keluarga, yang didasarkan pada kaidah-kaidah hukum yang berlaku, dapat disebut sebagai sebuah lembaga perkawinan. Dengan perkataan lain, bahwa perkawinan merupakan sebuah lembaga ikatan antara seorang pria dengan seorang wanita untuk membentuk keluarga, yang akan menimbulkan akibat lahir batin antara mereka dan terhadap masyarakat.

Perkawinan menurut Moediarti Trisnaningsih dalam buku Yunanto "Hukum Perkawinan Indonesia Kajian Kritis Atas Problematika dan Implementasinya” dijelaskan bahwa dalam sejarah kehidupan manusia perkawinan memiliki tiga makna dimensi yang saling terikat, yaitu': a). Dimensi sosial: Dimensi soial memiliki arti bahwa perkawinan selain sebagai wadah penerus keturunan, juga berfungsi untuk memperluas kekerabatan. Perkawinan bukan hanya mempersatukan jenis manusia yang berbeda dalam arti biologis, namun sekaligus mempertemukan dan menyatukan dua keluarga besar dari masing-masing pihak. b). Dimensi agama. Dimensi agama dalam perkawinan terlihat dari pengakuan masyarakat terhadap sistem keyakinan yang memberikan dogma bahwa otoritas tertinggi atas manusia dan alam adalah Tuhan. Hal ini menjadikan perkawinan tidak dapat

\footnotetext{
${ }^{1}$ Yunanto, Hukum Perkawinan Indonesia Kajian Kritis Atas Problematika dan Implementasinya, (Semarang: Badan Penerbit Universitas Diponegoro, 2010), halaman 43.
} 
terpisahkan dengan norma agama. Konsekuensi dari adanya pengakuan otoritas agama tersebut menjadikan legalitas perkawinan hanya dapat terwujud apabila memenuhi kriteria agama. c). Dimensi hukum: Dimensi hukum dalam perkawinan terlihat dari tujuan hukum sendiri yaitu, menyediakan seperangkat norma agar tercipta keseimbangan antara keadilan dan kepastian. Keseimbangan antara keadilan dan kepastian di dalam hukum merupakan upaya mengakomodasi berbagai kepentingan yang berkembang di dalam masyarakat. Posisi hukum dapat dikatakan dilematis, karena di dalam praktiknya hukum cenderung tidak dapat menyediakan perangkat norma secara ideal dan sempurna, bahkan dapat dikatakan sangat tidak mungkin menciptakan norma yang dapat memuaskan seluruh kepentingan masyarakat keseluruhan secara tuntas.

Sedangkan perkawinan menurut hukum adat memiliki artian tersendiri. Soepomo menjelaskan dalam buku Taufiqurrohman Syahuri, bahwa perkawinan bukan hanya persoalan mengenai orang-orang yang bersangkutan, dalam hal ini adalah suami dan istri, namun termasuk kepentingan seluruh keluarga dan bahkan masyarakat adat pun ikut berkepentingan dalam soal perkawinan tersebut. Bagi hukum adat perkawinan merupakan perbuatan yang tidak hanya bersifat keduniaan, melainkan juga bersifat kebatinan atau keagamaan $^{2}$. Hal ini berarti bahwa hukum adat mengartikan perkawinan sebagai kepentingan antara dua keluarga besar dan tidak hanya menyangkut hal duniawi saja, namun menyangkut pula agama atau kerohanian.

Pengertian perkawinan berdasarkan perundang-undangan negara telah termuat dalam Pasal 1 Undang-Undang Nomor 1 Tahun 1974 tentang Perkawinan menjelaskan bahwasanya "Perkawinan ialah ikatan lahir batin antara seorang pria dengan seorang wanita sebagai suami istri dengan tujuan membentuk keluarga (rumah tangga) yang bahagia dan kekal berdasarkan Ketuhanan Yang Maha Esa”.

Sedangkan perkawinan menurut pemahaman Masyarakat Hukum Adat pada umumnya, dipandang sebagai suatu peristiwa yang sangat penting. Perkawinan merupakan alat untuk

\footnotetext{
2 Taufiqurrohman Syahuri, Legislasi Hukum Perkawinan di Indonesia Pro-Kontra Pembentukannya Hingga
} Putusan Mahkamah Konstitusi, (Jakarta: Prenada Media Group, 2013), halaman 64. 
meraih keluhuran budi yang seterusnya untuk menciptakan atmaja tama (anak yang mulia). ${ }^{3}$

Pada dasarnya pelaksanaan perkawinan di dalam tatanan kehidupan masyarakat Indonesia masih dipengaruhi oleh hukum adat setempat. Pada tatanan kehidupan masyarakat Indonesia yang sangat beragam (plural) suku serta budayanya, sudah barang tentu hukum adanya beraneka ragam pula.

Pasal 2 ayat (1) Undang-Undang Nomor 1 Tahun 1974 tentang Perkawinan, memuat ketentuan tentang sahnya perkawinan, yakni "Perkawinan adalah sah, apabila dilakukan menurut hukum masing-masing agamanya dan kepercayaannya itu. Tiap-tiap perkawinan dicatat menurut peraturan perundang-undangan yang berlaku”.

Pasal 2 ayat (2) Undang-Undang Nomor 1 Tahun 1974 tentang Perkawinan, memuat ketentuan, bahwa: Pencatatan Perkawinan dari mereka yang melangsungkan perkawinan menurut agamanya dan kepercayaannya itu selain agama Islam, dilakukan oleh Pegawai Pencatat perkawinan pada kantor catatan sipil sebagaimana dimaksudkan dalam berbagai perundang-undangan mengenai pencatatan perkawinan”.

Berdasarkan Pasal 3 Ayat (1) Peraturan Pemerintah Republik Indonesia Nomor 9 Tahun 1975 tentang pelaksanaan Undang-Undang Nomor 1 Tahun 1974 tentang Perkawinan, menegaskan pula bahwa setiap orang yang akan melangsungkan perkawinan memberitahukan kehendaknya itu kepada Pegawai Pencatat di tempat perkawinan yang akan dilangsungkan.

Realita yang terjadi di masyarakat masih banyak perkawinan yang tidak dicatatkan di lembaga yang berwenang. Pencatatan perkawinan tersebut dibuktikan dengan akta perkawinan. Dalam hal ini apabila perkawinan dilakukan menurut Agama Islam maka dicatatkan oleh pegawai pencatat pada Kantor Urusan Agama setempat, sedangkan jika perkawinan dilaksanakan selain dengan ketentuan Agama Islam maka dicatatkan oleh pegawai pencatat perkawinan pada Kantor Catatan Sipil setempat.

Perkawinan penganut aliran kepercayaan saat ini masih harus menempuh perjalanan yang panjang dan terjal untuk bisa diakui negara. Persoalan muncul karena keyakinan

${ }^{3}$ Soerjanto Sastroatmojo, Masyarakat Samin; Siapakah Mereka?, (Yogyakarta: Narasi, 2003), hal. 77.

Administrative Law \& Governance Journal. Volume 3 Issue 1, March 2020 
mereka tidak diakui oleh negara dalam Undang-Undang Perkawinan. Mereka adalah penganut atau penghayat kepercayaan kepada Tuhan Yang Maha Esa ${ }^{4}$.

Sebagai suatu ketentuan peraturan perundangan negara yang akan membawa perubahan, maka Undang-Undang Nomor 1 Tahun 1974 tentang Perkawinan tidak terlepas dari adanya kendala-kendala, terutama dari tata cara perkawinan berdasarkan hukum adat masyarakat Indonesia yang telah lama digunakan sebagai ketentuan yang dianggapnya adil. Oleh karena itu, mengkaji penerapan suatu ketentuan baru, tidak terlepas dari pembicaraan tentang keefektifan ketentuan tersebut. Hal ini didasarkan suatu anggapan, bahwa ketentuan tersebut tidak langsung effectiveness begitu di umumkan, atau langsung dipatuhi. Suatu peraturan yang ditaati atau dipatuhi. Memerlukan proses pemasyarakatan yang evolusioner; untuk itu diperlukan penalaran dan penularan dari lingkungan tertentu untuk membentuk kesadaran yang diinginkan oleh Undang-Undang. Hal ini tentu akan melalui suatu proses. Di mana masyarakat dididik untuk mengenal, memahami., menghargai, dan mentaati norma baru yang akan diterapkan.

Sehubungan dengan tersebut di atas, maka Undang-Undang Nomor 1 Tahun 1974 yang berasas kan pada pencatatan perkawinan akan digunakan untuk mencapai tertib masyarakat yang dicita-citakan untuk melakukan perubahan-perubahan yang diinginkan. ${ }^{5}$

Meskipun perkawinan telah diatur dalam perundangan-undangan Negara sebagaimana tersebut di atas, bukan berarti masyarakat huku adat dapat dipastikan akan melaksanakan aturan tersebut. Sebagaimana yang diketahui pada masyarakat Adat Suku Samin atau Sedulur Sikep Desa Baturejo Kecamatan Sukolilo Kabupaten Pati Jawa Tengah, dan Masyarakat Adat Karuhun Urang (AKUR) di Cigugur Kabupaten Kuningan Jawa Barat Oleh karena itu penulis sangat tertarik untuk melakukan suatu penelitian berkaitan dengan Akibat hukum perkawinan yang tidak dicatatkan pada Masyarakat Hukum Adat

Berdasarkan uaian tersebut di atas, maka dapat dirumuskan permasalahan sebagai berikut: 1. Bagaimana pelaksanaan perkawinan yang dilakukan pada masyarakat Hukum

\footnotetext{
${ }^{4}$ Shaleh Harun, Latar Belakang Umat Islam Menerima Pancasila Sebagai Asas Tunggal, (Yogyakarta: Aquarius, 1984), halaman 79.

${ }^{5}$ Satjipto Rahardjo, Hukum dan Masyarakat, Angkasa, Bandung, 1980, Halaman 142.
} 
Adat? 2. Bagaimana akibat hukum apabila masyarakat Hukum Adat tidak mencatatkan perkawinannya di KUA atau Kantor Catatan Sipil?

\section{B. Pembahasan}

\section{Pelaksanaan Perkawinan Yang Dilakukan Pada Masyarakat Hukum Adat}

Istilah masyarakat hukum adat merupakan pengertian teknis yuridis yang menunjuk sekelompok orang yang hidup dalam suatu wilayah tempat tinggal dan lingkungan kehidupan tertentu, memiliki kekayaan dan pemimpin yang bertugas menjaga kepentingan kelompok baik keluar maupun kedalam, dan memiliki aturan hukum dan pemerintahan $^{6}$.

Konsep masyarakat hukum adat pertama kali diperkenalkan oleh Cornellius van Vollenhoven, yang selanjutnya di eksplor oleh murinya yang bernama Ter Haar. Ter Haar dalam buku Bushar Muhammad, menjelaskan bahwa di seluruh kepulauan Indonesia pada tingkatan rakyat jelata, terdapat pergaulan hidup di dalam golongangolongan yang bertingkah laku sebagai kesatuan terhadap dunia luar, lahir dan batin. Golongan-golongan itu mempunyai tata susunan yang tetap dan kekal, dan orang-orang segolongan itu masing-masing mengalami kehidupannya dalam golongan sebagai hal yang sewajarnya, hal tersebut merupakan kodrat alam. Tidak ada seorang pun dari mereka yang mempunyai pikiran akan memungkinkan pembubaran golongan itu. Golongan manusia tersebut mempunyai pula pengurus sendiri dan mempunyai harta benda, milik keduniaan dan milik gaib. Golongan-golongan demikian yang bersifat persekutuan hukum ${ }^{7}$.

Berbeda dengan pengertian masyarakat hukum adat menurut Aliansi Masyarakat Adat Nusantara (AMAN), pengertian masyarakat hukum adat diartikan bahwa kelompok masyarakat yang memiliki asal usul leluhur secara turun temurun di wilayah geografis tertentu, serta memiliki sistem nilai, ideologi, ekonomi, politik, budaya, sosial, dan wilayah sendiri. Pengertian masyarakat hukum adat dalam peraturan perundang-

\footnotetext{
${ }^{6}$ Taqwaddin, Penguasaan Atas pengelolaan Hutan Adat oleh Masyarakat Hukum Adat (Mukim) di Provinsi Aceh http://repository.usu.ac.id/handle/123456789/17216.

${ }^{7}$ Bushar Muhammad, Asas-Asas Hukum Adat Suatu Pengantar, (Jakarta: PT Pradnya Paramita, 2003), halaman 21.
} 
undangan, tertera dalam Pasal 1 angka 31 Undang-Undang Nomor 32 Tahun 2009 tentang Perlindungan dan Pengelolaan Lingkungan Hidup bahwa:

"Masyarakat hukum adat adalah kelompok masyarakat secara turun temurun bermukim di wilayah geografis tertentu karena adanya ikatan pada asal usul leluhur, adanya hubungan yang kuat dengan lingkungan hidup, serta adanya sistem nilai yang menentukan pranata ekonomi, politik, sosial dan hukum". Kriteria mengenai masyarakat hukum adat diatur pula dalam peraturan perundang-undangan. Hal ini dapat dilihat dalam Penjelasan Pasal 67 ayat (1) Undang-Undang Nomor 41 Tahun 1999 tentang Kehutanan, sebagai berikut: Masyarakatnya masih dalam bentuk paguyuban (rechtsgemeenschap); Ada kelembagaan dalam bentuk perangkat penguasa adatnya; Ada wilayah hukum adat yang jelas; Ada pranata dan perangkat hukum, khusunya peradilan adat yang masih ditaati; Masih mengadakan pemungutan hasil hutan di wilayah hutan sekitarnya untuk pemenuhan kebutuhan hidup sehari-hari;

Perkawinan menurut hukum adat merupakan peristiwa yang sangat penting dalam kehidupan manusia, sebab perkawinan itu tidak hanya menyangkut wanita dan pria bakal mempelai saja, namun juga orang tua, saudaranya, bahkan kerabatnya. Perkawinan bukan hanya peristiwa penting bagi mereka yang masih hidup saja, tetapi merupakan peristiwa yang sepenuhnya mendapat perhatian dan diikuti oleh arwah para leluhur kedua belah pihak. Oleh karenanya dan dari arwah leluhurnya diharapkan restunya, sehingga setelah melakukan perkawinan selanjutnya dapat hidup rukun dan bahagia sebagai suami-istri sampai "kaken-kaken ninen-ninen" (istilah Jawa yang artinya sampai sang suami menjadi kaki-kaki dan sang istri menjadi nini-nini yang bercucu-cicit) ${ }^{8}$.

Tujuan perkawinan dalam hukum adat pada umumnya adalah untuk mempertahankan dan meneruskan kelangsungan hidup dan kehidupan masyarakat adatnya. Sedangkan fungsi perkawinan bagi masyarakat hukum adat adalah bermanifestasi di dalam campur tangan kepala-kepala kerabat (clan), orang tua (ayahibu), kepala-kepala desa dengan pilihan kawin, bentuk perkawinan, upacara perkawinan. Perkawinan sebagai peristiwa hukum harus mendapat tempatnya didalam tata hukum,

${ }^{8}$ Soerojo Wignjodipoero, Pengantar dan Asas-Asas Hukum Adat, (Jakarta: PT Toko Gunung Agung, 1967), halaman 122. 
perbuatannya harus terang, para kepala persekutuan yang bersangkutan dalam hal ini juga menerima imbalan jasa atau legalisasinya9 .

Selanjutnya disampaikan tentang syarat perkawinan menurut Hukum Adat, yang dapat diklasifikasikan sebagai berikut ${ }^{10}$ : Mas kawin (Bride-Price). Mas kawin adalah sejumlah harta benda yang diberikan dari pihak laki-laki kepada pihak perempuan. Pembalasan jasa berupa tenaga kerja (Bride-Service). Pembalasan jasa berupa tenaga kerja merupakan syarat dalam keadaan darurat. Misalnya, suatu keluarga yang berpegang teguh pada prinsip patrilineal yang tidak memiliki anak laki-laki, kemungkinan keluarga tersebut akan mengambil anak laki-laki yang kurang mampu untuk dijadikan menantu untuk memenuhi persyaratan mas kawin dengan syarat bahwa anak laki-laki tersebut harus bekerja pada istrinya tersebut. Pertukaran gadis (Bride-Exchange). Pertukaran gadis merupakan laki-laki yang melamar perempuan untuk dinikahi, maka laki-laki tersebut harus mengusahakan perempuan lain dari kerabat perempuan yang dilamarnya untuk bersedia menikah dengan laki-laki kerabat calon istrinya.

\section{Akibat Hukum Apabila Masyarakat Hukum Adat Tidak Mencatatkan Perkawinannya Di KUA Atau Kantor Catatan Sipil}

Undang-Undang Nomor 1 Tahun 1974 tentang Perkawinan banyak terjadi penafsiran terhadap beberapa pasal, baik dari kalangan sarjana, pemerintah maupun masyarakat. Ada yang berpendapat bahwa Undang-Undang Nomor 1 Tahun 1974 tentang Perkawinan memiliki sifat yang universal bagi seluruh Warga Negara Indonesia (WNI), dan juga bersifat deferensial, karena sahnya perkawinan jika dilakukan sesuai dengan masing-masing hukum agama yang dipeluknya. Pasal 2 ayat (1) Undang-Undang Nomor 1 Tahun 1974 tentang Perkawinan menerangkan bahwa "Perkawinan adalah sah apabila dilakukan menurut hukum masing-masing agamanya dan kepercayaannya itu". Oleh karena itu perkawinan menurut hukum agama yang dipeluknya merupakan peristiwa hukum, yang tidak dapat dianulir oleh adanya peristiwa penting yang ditentukan dalam Pasal 2 ayat (2) Undang-Undang Nomor 1

\footnotetext{
${ }^{9}$ Iman Sudiyat, Hukum Adat Sketsa Asas, (Yogyakarta: Liberty, 1981), halaman 108.

${ }^{10}$ Laksanto Utomo, Opcit, halaman 92.
} 
Tahun 1974 tentang Perkawinan yang menerangkan bahwa "Tiap-tiap perkawinan dicatat menurut peraturan perundang-undangan yang berlaku”.

Namun ada pula yang berpendapat bahwa hakikat keabsahan yang dikehendaki oleh Undang-Undang Nomor 1 Tahun 1974 tentang Perkawinan adalah sah menurut hukum agama dan hukum negara. Pasal 2 ayat (1) dan ayat (2) merupakan satu kesatuan $^{11}$.

a. Akibat Perkawinan Tidak Dicatatkan Menurut Hukum Negara

Perkawinan menimbulkan akibat hukum bagi suami dan istri dalam perkawinan tersebut, diantaranya yaitu hubungan hukum antara suami dan istri, terbentuknya harta benda perkawinan, kedudukan dan status anak yang sah, serta hubungan pewarisan. Tidak terdaftarnya masyarakat Hukum Adat sebagai organisasi penghayat kepercayaan dalam Direktorat Kepercayaan Terhadap Tuhan yang Maha Esa dan Tradisi di Kementerian Pendidikan dan Kebudayaan memiliki konsekuensi. Salah satu konsekuensinya adalah masyarakat Hukum Adat tidak dapat mencatatkan perkawinannya di Kantor Catatan Sipil yang berakibat pada banyak lain hal, seperti:

1. Kedudukan dan status anak yang dilahirkan: Pasal 42 UU Perkawinan dijelaskan bahwa "Anak yang sah adalah anak yang dilahirkan dalam atau sebagai akibat perkawinan yang sah”. Perkawinan yang sah merupakan perkawinan menurut masing-masing agamanya. Perkawinan dicatatkan di Kantor Urusan Agama untuk yang beragama Islam, dan di Kantor Catatan Sipil bagi yang beragama selain Islam. Pencatatan tersebut dibuktikan dengan adanya akta perkawinan. Hal tersebut diatur dalam Pasal 2 ayat (1) dan (2) UU Perkawinan. Oleh karena itu, jika anak terlahir dari perkawinan yang tidak dicatatkan, maka status anak yang dilahirkan sama halnya dengan anak luar kawin. Akibatnya anak tersebut akan memiliki akta kelahiran yang hanya tercantum nama ibunya saja. Hal ini akan mempengaruhi psikologis anak, karena ia merasa berbeda dengan anak yang lain.

2. Pewarisan: Seperti yang sudah dijelaskan diatas, bahwa anak yang terlahir dari orangtua yang perkawinannya tidak dicatatkan, maka sama halnya dengan anak

${ }^{11}$ Yunanto, Pembaharuan Hukum Perkawinan di Indonesia ://ejournal2.undip.ac.id / index.php / dplr / article / view/3828. 
luar kawin. Akibatnya terhadap hak mewaris anak tersebut hanya memiliki hak mewaris terhadap ibunya dan keluarga ibunya saja. Hal tersebut dijelaskan juga dalam Pasal 43 ayat (1) Undang-Undang Nomor 1 Tahun 1974 tentang Perkawinan bahwa "Anak yang dilahirkan di luar perkawinan hanya mempunyai hubungan perdata dengan ibunya dan keluarga ibunya". Oleh karena itu, anak tidak dapat mewaris dari ayahnya dan tidak terjadi hubungan perdata dengan keluarga ayahnya.

3. Dampak pendidikan: Bagi anak yang merupakan masyarakat Hukum Adat yang melakukan pendidikannya di sekolah umum, maka anak tersebut diharuskan mengikuti pelajaran agama yang bukan merupakan kepercayaannya.

4. Dampak ekonomi: Terhambatnya peminjaman uang ke bank dikarenakan tidak adanya bukti mengenai akta perkawinan.

5. Dampak psikologis: Adanya diskriminasi terhadap pengadministrasian di kalangan Warga Negara Indonesia (WNI), yang seharusnya memiliki hak yang sama dalam pemenuhan pengadministrasian.

Bagi masyarakat Hukum Adat yang bekerja sebagai Aparatur Sipil Negara (ASN) memiliki akibat lebih, yaitu tunjangan anak dan istri yang tidak didapatkan. Perkawinan yang tidak dicatatkan juga sangat merugikan seorang perempuan karena perempuan tidak dianggap sebagai istri yang sah, istri tidak berhak atas nafkah dan warisan apabila suaminya meninggal dunia, istri tidak berhak atas harta gono-gini jika terjadi perceraian, karena perkawinan tersebut secara hukum tidak pernah terjadi.

Akibat hukum yang sudah diuraikan merugikan masyarakat Hukum Adat karena terdapat perlakuan diskriminasi terhadap perkawinan yang tidak dicatatkan di Kantor Catatan Sipil. Akibat hukum tersebut salah satunya terjadi pada akta kelahiran bagi anak yang belum dicatatkan perkawinannya memang di akta dapat ditulis nama ayah dan $\mathrm{ibu}$, namun tetap ada perbedaan yaitu catatan pinggir yang menjelaskan bahwa anak terlahir dari perkawinan yang belum dicatatkan. Selain itu masih banyak diskriminasi lain mengenai pengadministrasian terhadap masyarakat Hukum Adat, padahal dalam pasal 28D ayat (1) Undang-Undang Dasar Negara 
Republik Indonesia Tahun 1945 dijelaskan bahwa "setiap orang berhak atas pengakuan, jaminan, perlindungan, dan kepastian hukum yang adil serta perlakuan yang sama di hadapan hukum".

\section{Akibat Hukum Perkawinan Yang Tidak Dicatatkan Menurut Hukum Adat}

Perkawinan masyarakat Hukum Adat yang tidak dicatatkan di Kantor Catatan Sipil, menurut hukum adat mereka tidak menjadi masalah. Karena masyarakat Hukum Adat sudah memiliki pranata hukum adatnya sendiri, yang secara substantif terkait dengan pencatatan dan pengesahan melalui pranata hukum adat yang berlaku dimasyarakat adat setempat. Salah satu contoh yang terjadi pada Masyarakat Adat AKUR, akta perkawinannya disebut dengan Pranata Jatuk Rami. Perkawinan tersebut ditandatangani oleh sesepuh adat masyarakat Adat Karuhun Urang (AKUR). Sesepuh adat masyarakat Adat Karuhun Urang (AKUR) pada saat ini adalah Pangeran Djatikusumah dan Pangeran Gumirat.

Perkawinan dalam masyarakat Hukum Adat menimbulkan hubungan dua keluarga besar menjadi satu dalam ikatan persaudaraan. Jelaslah bahwa akibat hukum perkawinan masyarakat Hukum Adat tidak menjadi permasalahan yang signifikan, sebab dalam masyarakat hukum adat memang memiliki pranata hukum yang bersendikan pada asas komunal secara ketertiban dalam tatanan kehidupan masyarakat hukum adatnya.

\section{Simpulan}

Berdasarkan pembahasan yang telah diuraikan di atas, maka dapat disimpulkan sebagai berikut : Pertama, Pelaksanaan perkawinan di kalangan Masyarakat Hukum Adat melalui proses yang panjang atau rites de passage, karena menyatukan dua keluarga besar. Proses perkawinan yang diawali dengan lamaran, pertunangan, proses inti perkawinan, masuk dalam kehidupan baru sebagai suami isteri. Perkawinan sebagaimana yang terjadi seperti di lingkungan Masyarakat Hukum Adat Suku Samin atau Sedulur Sikep di Pati Jawa Tengah, dan Masyarakat Adat Karuhun Urang (AKUR) Kuningan Jawa Barat, tidak dicatatkan di KUA atau Kantor Catatan Sipil, namun memiliki pencatatan secara administratif tersendiri di lembaga adatnya. Seperti kalau pada Masyarakat Adat Karuhun 
Urang (AKUR) Kuningan Jawa Barat, ditandatangani oleh sesepuh adat yang disebut dengan Pranata Jatuk Rami.

Kedua, Akibat hukum perkawinan masyarakat Hukum Adat yang tidak mencatatkan perkawinannya di KUA atau Kantor Catatan Sipil secara hukum negara berdampak pada beberapa hal, seperti halnya kedudukan dan status anak yang dilahirkan, pewarisan, dampak pendidikan. Akibat hukum lainnya apabila ada warga masyarakat Hukum Adat yang akan menjadi Aparatur Sipil Negara (ASN). Sedangkan akibat hukum menurut hukum adatnya tidak menjadi masalah karena perkawinan sudah memiliki pengakuan dalam tatanan kehoidupan Masyarakat Hukum Adatnya. Perkawinan tersebut menimbulkan hubungan dua keluarga besar menjadi satu, serta tidak dipermasalahkan yang terkait dengan hak kedudukan anak, seperti dibidak pendidikan informal, warisan, perkawinan. Semuanya dikembalikan pada hukum adat yang berlaku dalam masyarakat Hukum Adat setempat.

\section{Daftar Pustaka}

Harun, Shaleh. 1984. Latar Belakang Umat Islam Menerima Pancasila Sebagai Asas Tunggal. Yogyakarta: Aquarius.

Muhammad, Bushar. 2003. Asas-Asas Hukum Adat Suatu Pengantar. Jakarta: PT Pradnya Paramita.

Rahardjo, Satjipto, 1980, Hukum dan Masyarakat, Bandung: Angkasa,

Sastroatmojo, Soerjanto, 2003, Masyarakat Samin; Siapakah Mereka?, Yogyakarta: Narasi.

Sudiyat, Iman. 1981. Hukum Adat Sketsa Asas. Yogyakarta: Liberty.

Syahuri, Taufiqurrohman. 2013. Legislasi Hukum Perkawinan di Indonesia Pro-Kontra Pembentukannya Hingga Putusan Mahkamah Konstitusi, Jakarta: Prenada Media Group.

Utomo, Laksanto. 2017. Hukum Adat. Depok: PT. Rajagrafindo Persada.

Wignjodipoero, Soerojo. 1983. Pengantar dan Asas-Asas Hukum Adat. Jakarta: PT Toko Gunung Agung.

Yunanto. 2010. Hukum Perkawinan Indonesia Kajian Kritis Atas Problematika dan Implementasinya. Semarang: Badan Penerbit Universitas Diponegoro.

Taqwaddin. Penguasaan Atas pengelolaan Hutan Adat oleh Masyarakat Hukum Adat (Mukim) di Provinsi Aceh http://repository.usu.ac.id/handle/123456789/17216

Yunanto. Pembaharuan Hukum Perkawinan di Indonesia https://ejournal2.undip.ac.id/index.php/dplr/article/view/3828 di akses pada tanggal 20 Februari 2019 pukul 10.22 WIB.

Undang-Undang Dasar Negara Republik Indonesia 1945.

Undang-Undang Nomor 1 Tahun 1974 tentang Perkawinan. 